\title{
STAINLESS STEEL AS A MATERIAL FOR FUEL-CELL BIPOLAR PLATES
}

\author{
Tomáš LOVAŠI, Milan KOUŘIL, Tereza JAMBOROVÁ, Vojtěch PEČINKA \\ University of Chemistry and Technology Prague, Department of Metals and Corrosion Engineering, Prague, \\ Czech Republic, EU, lovasit@vscht.cz
}

https://doi.org/10.37904/metal.2019.879

\begin{abstract}
Stainless steels are considered to be a perspective candidate as a bipolar plate material for the polymer electrolyte membrane fuel cells. The main reasons for using this material are properties such as low cost, high strength, electrical and heat conductivity and reasonable corrosion resistance. The aim of this study was to test several stainless steels in simulated environment (acidic and humid environment at $80^{\circ} \mathrm{C}$ ) for application as bipolar plates. The experiments were carried out in an electrolyte of $\mathrm{pH} 3$ with addition of $0.1 \mathrm{ppm} \mathrm{HF}$. Potentiodynamic and potentiostatic polarization according to United States Deparments of Energy was used for electrochemical testing. Open circuit potential, polarization resistance, corrosion current density and corrosion rate from the Tafel extrapolation were determined on the basis of measured data. The suitability of using different types of stainless steels as a bipolar plate material for fuel cell has been evaluated.
\end{abstract}

Keywords: Stainless steels, corrosion, bipolar plates

\section{INTRODUCTION}

As a replacement for a combustion engine, the use of polymer electrolyte membrane fuel cells (PEMFC) is being considered in the near future to convert chemical energy into electrical energy. [1,2]. The fuel cell itself should have a number of positives over a conventional combustion engine. The main advantages are for example eco-friendliness (noise and emissions), low-temperature work, allowing faster start-up and immediate response to changing performance and greater energy efficiency. [3,4]. At present, there are several shortcomings that defend greater use of fuel cells in normal practice. An example is the price which is associated with their production and the need to reduce weight and volume when considering use in automobile transport [5]. Due to the large number of requirements that are put on fuel cells, DOE limits (US Department of Energy) have been developed to provide sufficient durability and performance. [6]. DOE requirements are summarized in Table 1. The price of the fuel cell is reflected in the price of the material used for the individual components, while the cost of the bipolar plates is significant part of the price. PEMFC consist of two essential parts, a gas diffusion layer and a catalyst layer (MEA - membrane electrode assembly), which are placed between the bipolar plates. The solid electrolyte in the PEMFC is a membrane. The most commonly used membrane - perfluorosulfonic acid-base polymer (PFSA) - has a main chain formed by Teflon and side chains terminated by sulfonic acid groups $\left(\mathrm{HSO}_{3}\right)$ [5]. As for the bipolar plates themselves (sometimes also called end plates, depending on the design), they are made of graphite or carbon composite because of its electrical properties and chemical stability. However, the disadvantages of this material are its fragility and porosity. Material to bipolar plates is required to meet the current DOE limits. Therefore, it is necessary to find a suitable substitute for graphite. Therefore, current research has been focused on the use of metallic materials using conductive coatings with corrosion-resistant properties [7]. Major non-ferrous metal candidates include titanium, copper, nickel, magnesium or aluminum and their alloys (and alloys of these metals). The disadvantage of these materials is that they must be coated, or their purchase price is high. Another possible substitute being tested is stainless steel [8-11]. This material is very perspective due to the combination of good mechanical properties, electrical and thermal conductivity. It is also affordable and relatively easy to machine. Stainless steels are prone to corrosion in an environment where the fuel cell should be operated. However, corrosion resistance can be increased by coating as in non-ferrous metals. Most attention is focused 
on austenitic stainless steels, especially steels AISI 316L. Austenitic stainless steels 304,310 and 316 are less tested. Superaustenitic stainless steels such as 254 SMO and 904L or duplex stainless steels such as 2205 are also considered $[12,13]$.

Table 1 DOE limits

\begin{tabular}{|c|c|c|}
\hline Characteristic & 2020 Target & Notes \\
\hline Cost & $<3 \$ \mathrm{~kW}^{-1}$ & 2002 dollars, 500,000 stacks per year \\
\hline Corrosion resistance (anode) & $<1 \mu \mathrm{A} \mathrm{cm}-2$ & $\begin{array}{l}\mathrm{pH} 3,0.1 \mathrm{ppm} \mathrm{HF}, 80^{\circ} \mathrm{C}, \text { Ar purge } \\
\text { Potentiodynamic test } \\
-0.4 \mathrm{~V}-0.6 \mathrm{~V}(\mathrm{Ag} / \mathrm{AgCl}), 0.1 \mathrm{mV} / \mathrm{s}\end{array}$ \\
\hline Corrosion resistance (cathode) & $<1 \mu \mathrm{A} \mathrm{cm}-2$ & $\begin{array}{l}\mathrm{pH} 3,0.1 \mathrm{ppm} \mathrm{HF}, 80^{\circ} \mathrm{C} \text {, aerated } \\
\text { Potentiostatic test } \\
(>24 \mathrm{~h}) 0.6 \mathrm{~V}(\mathrm{Ag} / \mathrm{AgCl}), \mathrm{i}_{\text {passive }}<50 \mathrm{nA} \mathrm{cm}^{-2}\end{array}$ \\
\hline Electrical conductivity & $>100 \mathrm{~S} \mathrm{~cm}^{-1}$ & - \\
\hline Areal specific resistance & $<0.01 \Omega \mathrm{cm}^{2}$ & including contact resistance at $138 \mathrm{~N} \mathrm{~cm}^{-2}$ \\
\hline Hydrogen premeability & $<1.3 .10^{-14} \mathrm{~cm}^{3}$ & ASTM D1434, $80^{\circ} \mathrm{C}, 3 \mathrm{~atm}, 100 \% \mathrm{RH}$ \\
\hline Flexural strength & $>25 \mathrm{MPa}$ & ASTM D790-10 \\
\hline Forming elongation & $40 \%$ & ASTM E8M-01 \\
\hline
\end{tabular}

\section{EXPERIMENT}

\subsection{Specimens and simulated solutions}

For this study was chosen two type of stainless steel, AISI 316L and super-austenitic AISI 904L. Chemical composition of the steel specimens used in this study is shown in Table 2.

Table 2 Main chemical composition of study steels

\begin{tabular}{|c|c|c|c|c|c|}
\hline Element (wt. \%) & $\mathrm{C}$ & $\mathrm{Cr}$ & $\mathrm{Ni}$ & Mo & $\mathrm{Mn}$ \\
\hline $316 \mathrm{~L}$ & $<0.03$ & $16-18$ & $10-12$ & $2-2.5$ & 2 \\
\hline $904 \mathrm{~L}$ & $<0.02$ & $19-21$ & $24-26$ & $4-5$ & 2 \\
\hline
\end{tabular}

The specimens were machined into cylinders with diameter $16 \mathrm{~mm}$. Before exposure, the working surface of specimen was polished with 1200 grit silicon carbide abrasive paper, rinsed with distillated water and ethanol and dried. The microstructure of stainless steel $361 \mathrm{~L}$ is shown in Figure 1.

Before every measurement was prepared fresh simulated solutions. The model solution was prepared a mixture with $1 \mathrm{ml}$ of $0.01 \%$ hydrofluoric acid and demineralized water. Sulfuric acid was used to adjust the $\mathrm{pH}$ to value 3 . Concentration on this acid was $1 \mathrm{M}$ and was added into solution dropwise.

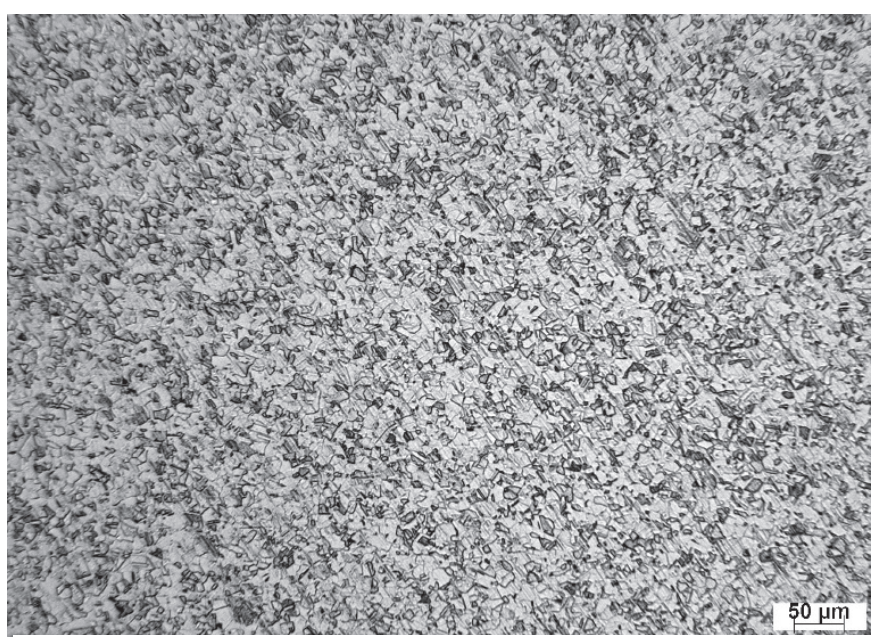

Figure 1 The microstructure of AISI 316L 


\subsection{Electrochemical measurements}

The electrochemical experiments were carried out in a corrosion cell consisting of a three-electrode arrangement. Model solution in corrosion cell was heated with using thermostat on temperature $80^{\circ} \mathrm{C}$ and was mixed for homogeneous temperature in full volume of the corrosion cell during the electrochemical

measurements. The specimen served as the working electrode and platinum wire was used as a counter electrode. A platinum sheet with area $0.5 \mathrm{~mm}^{2}$ was used as a reference electrode. A saturated calomel electrode was connected with salt bridge (filled whit simulated solution). This electrode was used to measure the open circuit potential of platinum sheet in a corrosion cell. A Zahner Zennium electrochemical workstation was used to perform the electrochemical measurements and the Thales XT Analysis software was used for electrochemical data processing. Each experiment was repeated two times to ensure reproducibility of the results. The electrochemical measurement consisted of measuring the open circuit potential for 1800 seconds. This was followed by a measurement of polarization resistance $( \pm 20 \mathrm{mV} / \mathrm{OCP}$, scan rate $0.1 \mathrm{mV} / \mathrm{s})$. Measurement of potentiodynamic curves was the last measurement. Setup for cathodic part of polarization curve was $+100 \mathrm{mV}$ OCP $-1.2 \mathrm{~V}$ with scan rate $5 \mathrm{mV} / \mathrm{s}$. For the anodic part, the scan rate was the same, while the sample was polarized in the range $-100 \mathrm{mV}$ OCP $1.5 \mathrm{~V}$.

\section{RESULTS AND DISCUSSION}

After the specimen was immersed in corrosion simulated solution, the corrosion potential $E_{\text {corr }}$ and the current density $i_{c o r r}$ can be measured by an electrochemical method. Corrosion potential and current density are widely used as indicators of the material corrosion resistance. A high corrosion potential and low current density indicate that corrosion of material is retarded. Figure 2 shows potentiodynamic polarization curves for stainless steel $316 \mathrm{~L}$ and $904 \mathrm{~L}$ in model solution at $80^{\circ} \mathrm{C}$.

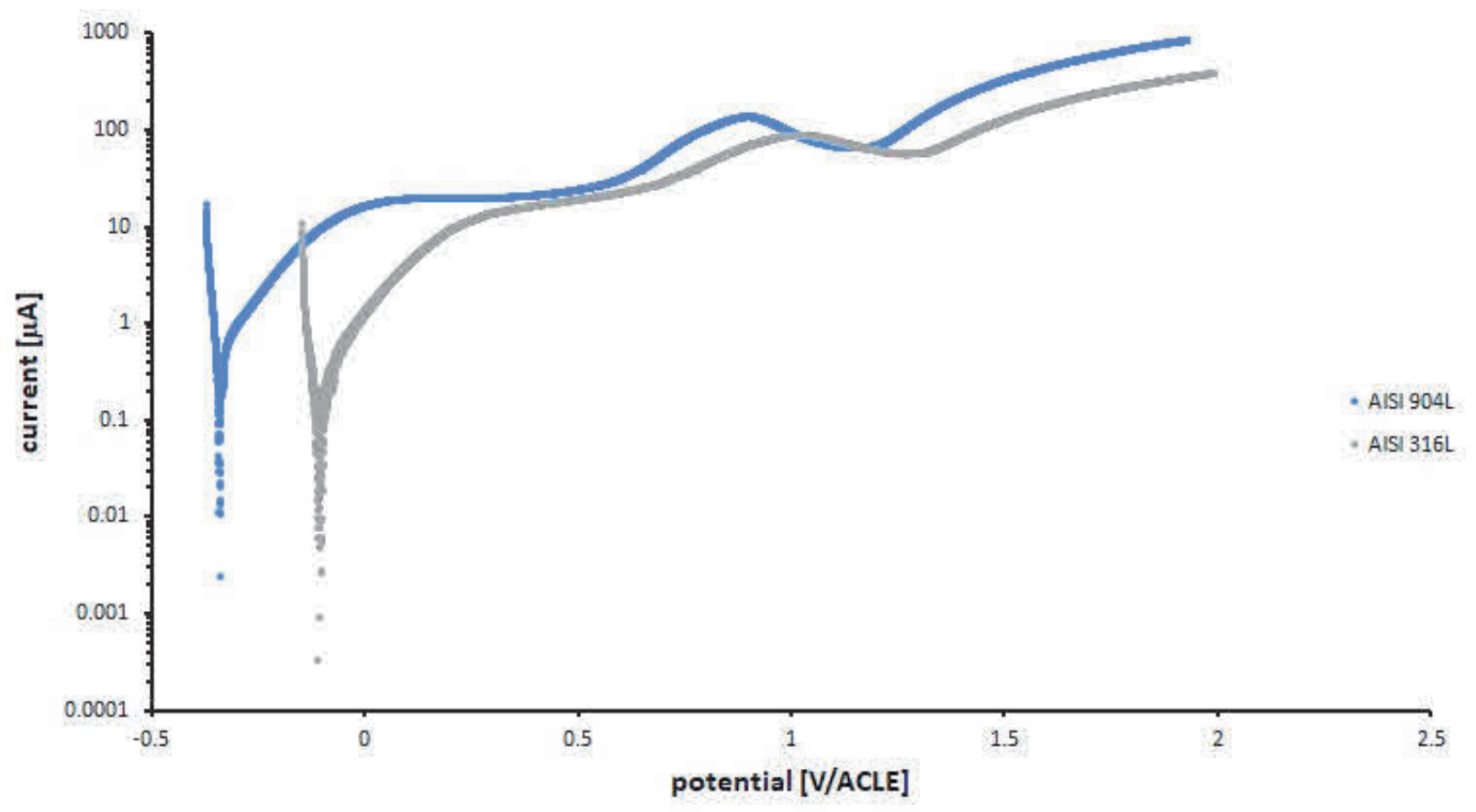

Figure 2 Anodic part of polarization curves of stainless steel AISI $316 \mathrm{~L}$ and $904 \mathrm{~L}$ in model solution at $80^{\circ} \mathrm{C}$

The values of the relevant electrochemical parameters, i.e., corrosion potential ( $\left.E_{\text {corr }}\right)$, corrosion current density (icorr), anodic $\left(\beta_{\mathrm{a}}\right)$ and cathodic $\left(\beta_{\mathrm{c}}\right)$ Tafel slopes, are extracted from the potentiodynamic polarization curves and are summarized in Table 3. These data were obtained by fitting the polarization curves shown in Figure 2 
and Figure 3. The polarization resistance values were obtained from the measured data, which were evaluated in the range of $\pm 10 \mathrm{mV} / \mathrm{OCP}$. It can be seen in Figure 3 that the cathodic Tafel slope $\left(\beta_{c}\right)$ is very similar. While in the anodic Tafel slope $\left(\beta_{\mathrm{a}}\right)$, a passive region appears of steel $904 \mathrm{~L}$.

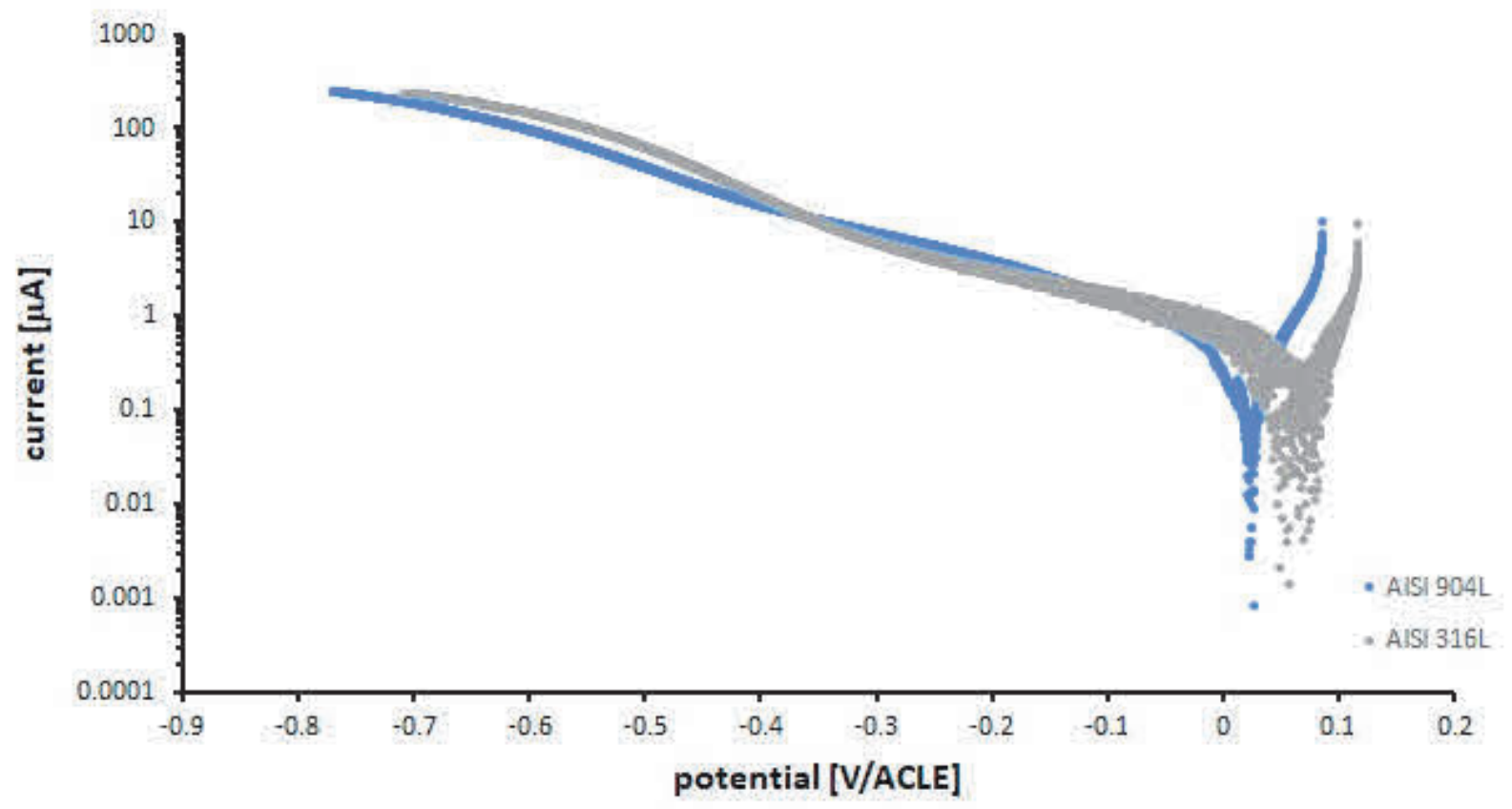

Figure 3 Cathodic part of polarization curves of stainless steel AISI 316L and 904L in model solution at $80^{\circ} \mathrm{C}$

Table 3 Polarization parameters of stainless steels at $80^{\circ} \mathrm{C}$ in model solution

\begin{tabular}{|c|c|c|c|c|c|c|}
\hline Specimen & $\boldsymbol{\beta}_{\mathrm{a}}$ (V/decade) & $\boldsymbol{\beta}_{\mathrm{c}}$ (V/decade) & $\mathrm{E}_{\text {corr }}$ (V/ACLE) & $\mathbf{i}_{\text {corr }}\left(\mathbf{A ~ m}^{-2}\right)$ & $\mathbf{V}_{\text {corr }}(\boldsymbol{\mu m} / \mathbf{a})$ & $\mathbf{R P}\left(\Omega \mathbf{m}^{2}\right)$ \\
\hline $316 \mathrm{~L}$ & 0.187 & -0.243 & -0.131 & 0.035 & 27.2 & 10.1 \\
\hline $904 \mathrm{~L}$ & 0.175 & -0.284 & -0.228 & 0.015 & 11.7 & 13.2 \\
\hline
\end{tabular}

\section{CONCLUSION}

In this study, stainless steel AISI 316L and AISI 904L were compared. Stainless steels have been investigated in $1 \mathrm{M} \mathrm{H}_{2} \mathrm{SO}_{4}+1 \mathrm{ppm} \mathrm{F}$ - at $80^{\circ} \mathrm{C}$ in simulating an aggressive bipolar plate condition in a PEMFC environment. Both linear sweep voltammetry and potentiodynamic curves measurements indicated that the performance of the steels improved with the increase in the chromium content in the alloy, with AISI 904L being the better candidate for the application as a material for bipolar plates.

\section{ACKNOWLEDGEMENTS}

This section includes acknowledgment of people, grant details, funds, etc. Size font is 10 pt, italics, gaps 6 and 0 , bold, center align.

\section{REFERENCES}

[1] CHANG, K.-Y., The optimal design for PEMFC modeling based on Taguchi method and genetic algorithm neural networks. International Journal of Hydrogen Energy, 2011. 36(21): p. 13683-13694.

[2] YU, Y., et al., Corrosion-resistant characteristics of nitrided Ni-free stainless steel for bipolar plate of polymer electrolyte fuel cell. International Journal of Hydrogen Energy, 2017. 42(9): p. 6303-6309. 
[3] WANG, X.-Z., H. LUO, and J.-L. LUO, Effects of hydrogen and stress on the electrochemical and passivation behaviour of 304 stainless steel in simulated PEMFC environment. Electrochimica Acta, 2019. 293: p. 60-77.

[4] YANG, G., et al., A novel PEMEC with 3D printed non-conductive bipolar plate for low-cost hydrogen production from water electrolysis. Energy Conversion and Management, 2019. 182: p. 108-116.

[5] OGUNGBEMI, E., et al., Fuel cell membranes - Pros and cons. Energy, 2019. 172: p. 155-172.

[6] HINDS, G. and E. BRIGHTMAN, Towards more representative test methods for corrosion resistance of PEMFC metallic bipolar plates. International Journal of Hydrogen Energy, 2015. 40(6): p. 2785-2791.

[7] ASRI, N.F., et al., Coating of stainless steel and titanium bipolar plates for anticorrosion in PEMFC: A review. International Journal of Hydrogen Energy, 2017. 42(14): p. 9135-9148.

[8] ANDRÉ, J., L. ANTONI, and J.-P. PETIT, Corrosion resistance of stainless steel bipolar plates in a PEFC environment: A comprehensive study. International Journal of Hydrogen Energy, 2010. 35(8): p. 3684-3697.

[9] WANG, H., M.A. SWEIKART, and J.A. TURNER, Stainless steel as bipolar plate material for polymer electrolyte membrane fuel cells. Journal of Power Sources, 2003. 115(2): p. 243-251.

[10] YANG, Y., L.-J. GUO, and H. LIU, Corrosion characteristics of SS316L as bipolar plate material in PEMFC cathode environments with different acidities. International Journal of Hydrogen Energy, 2011. 36(2): p. 16541663.

[11] MIYAZAWA, A., E. TADA, and A. NISHIKATA, Influence of corrosion of SS316L bipolar plate on PEFC performance. Journal of Power Sources, 2013. 231: p. 226-233.

[12] LI, D.G., et al., Molybdenum addition enhancing the corrosion behaviors of $316 \mathrm{~L}$ stainless steel in the simulated cathodic environment of proton exchange membrane fuel cell. International Journal of Hydrogen Energy, 2015. 40(17): p. 5947-5957.

[13] JINLONG, L., et al., Enhancing the corrosion resistance of the 2205 duplex stainless steel bipolar plates in PEMFCs environment by surface enriched molybdenum. Results in Physics, 2017. 7: p. 3459-3464. 